\title{
English Language Instructors' Perceptions and Practices of Formative Assessment
}

\author{
MOHAMMED SHERKO TAHER MALAZADA \\ Department of English Language and Literature, Istanbul Aydın University, Istanbul - Turkey
}

\begin{abstract}
Formative assessment is a kind of evaluation that takes place during the course of learning. In this type of assessment, the teacher and the students are actively engaged in the process of learning to discover whether the learning targets are achieved or not (Black \& William, 2009). The teachers who use formative assessment modify their teaching strategies according to the learner needs. The learners become more independent as they learn to evaluate their own progress. The main goal of this study was to investigate English language teachers' perceptions and practices of formative assessment. In addition to discover the types of formative assessment English language instructors' prefer to use. This study was conducted with 50 English language instructors who teach at Salahaddin University in Erbil, Iraq in 2018-2019 academic year. In this study, quantitative research design was used. The data of this study was gathered via a questionnaire that was originally developed by Pat-El et al. (2013) and later adapted by Öz (2014). The findings of this study revealed that language instructors are well-aware of the importance of giving support to their students in the language learning process. It also became clear that all of the language instructors give feedback about the examination results yet less than half of them ignore sharing the examination papers with the students, which rarely help the learners to learn from their mistakes and/or their weaknesses to improve their language skills as pointed out by many researchers (Wiggins \& McTighe, 2007; Black \& William, 1998; Herrera, Murry \& Cabral, 2007). Almost all of the instructors in the present study are open to make modifications in their teaching practices on noticing any problems in students' achievement of their learning goals and most of them are well aware of the importance of using questioning strategies to improve student learning. The findings of the study showed that the instructors prefer using the Multiple-choice and the Short-answer Exam methods of assessment the most, which are not considered as methods of formative assessment. The second most frequently preferred assessment methods are Essays, Fill in the Blanks, True and False, Matching, Oral Presentation, Peer Assessment and Group Work exams. Finally, Oral exams, Drama, Project, Portfolio, Performance Assessment, Self-Assessment, Observation Form, Structured Grid, are Rubric considered as the third preferred methods of assessment by English instructors.
\end{abstract}

Keywords: English language teaching, Formative Assessment, Formative Assessment Practices

DOI: $10.7176 / J L L L / 62-04$

Publication date: November $30^{\text {th }} 2019$

\section{Introducation}

Learning assessment has always become a discussable matter. The origin of the word assessment is proposed in the 20th century. Assessment is considered as a crucial step of the process of teaching and learning. Additionally, through the regular assessments, students' improvement can be recorded systematically (Dhindsa, Omar \& Waldrip, 2007). The process of assessment in general is essential to observe the learners' progression of the learning (Struyven, Dochy and Janssens, 2005). However, these days language assessment during the course of learning has been widely discussed to let the learners to be a part of the course. According to Herrera, Murry and Cabral (2007), the whole method of teaching has been changed recently. In other words, they claim that students are now being involved in the process of learning. The researchers have given the alternative method of assessement a name called "Formative Assessment". As a result numorous studies have been conducted to investigate the perceptions of Formative Assessment and its impact on the process of learning such as (Sharma, 2006; Farrell \& Jacobs, 2010; Black \& Williams, 1998; Herrera, Murry \& Cabral, 2007; Gottlieb, 2006). Due to the significance of the formative in the process of learning, it is worth to examine the English language instructors' competence to find out their perceptions. The present study endeavors to address the following up three research questions: What are English language instructors' perceived monitoring practices of formative assessment? What are English language instructors' perceived scaffolding practices of formative assessment? What types of formative assessment do English language instructors prefer to use?

\section{Methods}

Fifty English language instructors became the participants of the study, mixed in gender, who teach at Salahaddin University-Erbil. During collecting the information, these instructors were teaching at certain colleges/departments such as college of Language, college of Education, college of basic Education and Salahaddin University-Erbil Language Centre. When choosing the participants of the study convenience 
sampling strategy was used. Convenience sampling strategy is a kind of non-probability sampling method of data collection (Lavrakas, 2008).

The data of this study was gathered via a questionnaire called "Assessment for Learning Questionnaire for Teachers", which was originally developed by Pat-El et al. (2013) and later adapted by Öz (2014) (see Appendix 1). The questionnaire is divided into two sections. The aim of the first section is to collect background and demographic information about the participants of the study including gender, years of teaching experience, types of school that teachers are currently working for and the teachers' preferred methods of assessment in language teaching (see Section 3.2). The first part of the questionnaire was developed by Öz (2014). The second part of the questionnaire deals with English language teachers' perceived monitoring and scaffolding practices of formative assessment. The second part of the questionnaire involves twenty-eight statements based on a 5-point Likert type rating scale ranging from 1 "Strongly Disagree" to 5 "Strongly Agree". English language teachers" perceived monitoring practices of formative assessment were elicited through the responses given to Items 1-16, while their perceived scaffolding practices of formative assessment are gathered through Items 17-28. The quantitative data gathered from the questionnaire was subjected to the statistical package for social sciences (SPSS) software, version 22 (SPSS Inc. USA).

\section{Result and Discussion}

Research questions: 1. What are English language instructors' perceived monitoring practices of formative assessment?

Table 4.1: Instructors Perceived Monitoring Practices of Formative Assessment

The statements 1-16 (Perceived Monitoring)

1. I encourage my students to reflect upon how they can improve their language learning

2. After a test, I discuss the answers given with each student

3. While working on their assignments, I ask my students how they think they are doing

4. I involve my students in thinking about how they want to learn English at school

5. I give my students the opportunity to decide on their language learning objectives

6. I ask my students to indicate what went well and what went badly concerning their assignments

7. I encourage students to reflect upon their learning processes and how to improve their learning

8. I inform my students on their strong points concerning language learning

9. I inform my students on their weak points concerning language learning.

10. I encourage my students to improve on their language learning processes

11. I give students guidance and assistance in their language learning

12. I discuss assignments with my students to help them understand the content better

13. I discuss with my students the progress they have made in learning English

14. After an assessment, I inform my students on how to improve their weak points 15 I discuss with my students how to utilize their strengths to improve on their assignment

16 Together with my students, I consider ways on how to improve on their weak points

\begin{tabular}{|c|c|c|c|c|c|c|c|c|c|c|}
\hline \multicolumn{2}{|c|}{$\begin{array}{l}\text { Strongly } \\
\text { Disagree }\end{array}$} & \multicolumn{2}{|c|}{ Disagree } & \multicolumn{2}{|c|}{ Neutral } & \multicolumn{2}{|c|}{ Agree } & \multicolumn{2}{|c|}{$\begin{array}{c}\text { Strongly } \\
\text { Agree }\end{array}$} & \multirow[t]{2}{*}{ Mean } \\
\hline $\mathbf{f}$ & $\%$ & $\mathbf{F}$ & $\%$ & f & $\%$ & f & $\%$ & $\mathbf{f}$ & $\%$ & \\
\hline 1 & 2 & 2 & 4 & 9 & 18 & 28 & 56 & 10 & 20 & 3.88 \\
\hline 1 & 2 & 10 & 20 & 17 & 34 & 16 & 32 & 6 & 12 & 3.32 \\
\hline 1 & 2 & 7 & 14 & 11 & 22 & 22 & 44 & 9 & 18 & 3.62 \\
\hline 2 & 4 & 4 & 8 & 12 & 24 & 25 & 50 & 7 & 14 & 3.62 \\
\hline 2 & 4 & 4 & 8 & 17 & 34 & 20 & 40 & 7 & 14 & 3.52 \\
\hline 1 & 2 & 4 & 8 & 14 & 28 & 21 & 42 & 10 & 20 & 3.7 \\
\hline 0 & 0 & 5 & 10 & 6 & 12 & 30 & 60 & 9 & 18 & 3.86 \\
\hline 1 & 2 & 3 & 6 & 16 & 32 & 19 & 38 & 11 & 22 & 3.72 \\
\hline 0 & 0 & 2 & 4 & 15 & 30 & 23 & 46 & 10 & 20 & 3.82 \\
\hline 1 & 2 & 2 & 4 & 11 & 22 & 24 & 48 & 12 & 24 & 3.88 \\
\hline 1 & 2 & 2 & 4 & 8 & 16 & 25 & 50 & 14 & 28 & 3.98 \\
\hline 5 & $\begin{array}{l}1 \\
0\end{array}$ & 1 & 2 & 9 & 18 & 22 & 44 & 13 & 26 & 3.74 \\
\hline 2 & 4 & 1 & 2 & 13 & 26 & 28 & 56 & 6 & 12 & 3.7 \\
\hline 2 & 4 & 5 & 10 & 9 & 18 & 25 & 50 & 9 & 18 & 3.68 \\
\hline 2 & 4 & 3 & 6 & 12 & 24 & 27 & 54 & 6 & 12 & 3.64 \\
\hline 1 & 2 & 7 & 14 & 14 & 28 & 23 & 46 & 5 & 10 & 3.48 \\
\hline
\end{tabular}


As shown in Table 4.1, the mean scores gained for the statements 1-16 display the monitoring factors were close to the scale. Most of the participants of the study have chosen "Neutral" or "Agree" from the questionnaire (see Table 4.1). As seen, Statement 11 has the highest mean (3.98). Table 4.1 shows that 26 participants strongly believe that English students need the teacher guidance and assistance during the course of learning. This could tell us that the participants monitor their students and follow their needs. It also shows that most of the participants tend to help their students within the process of learning. There are plenty ways of supporting and assisting students such as giving advice to guide and help the students. Black and William (1998) also argue that teachers can give advice to their students based on their observations while the students are on task. They also add that the teachers' feedback could always help the students to improve their weaknesses in language learning process. This kind of assistance can be given during the course of learning which students can find it useful. On the other hand, the lowest mean (3.32) has gone to Statement 2 (see Table 4.1). This is an evidence to indicate that the English university instructors are less interested in sharing the exam results with their students. Therefore, the students would have less opportunity to know their mistakes from exam papers. It seems that most of the English university instructors arrange mid-term and final examinations for their students, which rarely help the learners to improve their skills (Wiggins \& McTighe, 2007; Black \& Wiliam, 1998; Herrera, Murry \& Cabral, 2007). However, considering the responses given to this statement as the lowest mean in the whole questionnaire, there are still some instructors with the percentage \%34, who selected the option "Neutral", meanwhile those instructors who had chosen the option "Agree" with a percentage of \%32. In other words, the findings indicate that $\% 66$ of the participants showed their agreement to discuss the exam papers with their students to indicate the problems later fulfil the needs.

Research questions: 2. What are English language instructors' perceived scaffolding practices of formative assessment?

Table 4.2: Instructors Perceived Scaffolding Practices of Formative Assessment

\begin{tabular}{|c|c|c|c|c|c|c|c|c|c|c|c|}
\hline \multirow[t]{2}{*}{$\begin{array}{lll}\text { The statements } & 17-28 & \text { (Perceived } \\
\text { Scaffolding) } & & \end{array}$} & \multicolumn{2}{|c|}{$\begin{array}{l}\text { Strongly } \\
\text { Disagree }\end{array}$} & \multicolumn{2}{|c|}{$\begin{array}{c}\text { Disagre } \\
\mathrm{e}\end{array}$} & \multicolumn{2}{|c|}{ Neutral } & \multicolumn{2}{|c|}{ Agree } & \multicolumn{2}{|c|}{$\begin{array}{l}\text { Strongly } \\
\text { Agree }\end{array}$} & \multirow[t]{2}{*}{ Mean } \\
\hline & $\mathrm{f}$ & $\%$ & F & $\%$ & f & $\%$ & $\mathrm{f}$ & $\%$ & $\mathrm{f}$ & $\%$ & \\
\hline $\begin{array}{l}\text { 17. I adjust my language teaching } \\
\text { whenever I notice that my students do } \\
\text { not understand a topic }\end{array}$ & 3 & 6 & 3 & 6 & 2 & 4 & 20 & 40 & 22 & 44 & 4.1 \\
\hline $\begin{array}{l}\text { 18. I provide my students with guidance } \\
\text { to help them gain understanding of the } \\
\text { content taught }\end{array}$ & 3 & 6 & 4 & 8 & 5 & 10 & 29 & 58 & 9 & 18 & 3.74 \\
\hline $\begin{array}{l}\text { 19. During my class, students are given } \\
\text { the opportunity to show what they have } \\
\text { learned. }\end{array}$ & 2 & 4 & 6 & 12 & 10 & 20 & 17 & 34 & 15 & 30 & 3.74 \\
\hline $\begin{array}{l}\text { 20. I ask questions in a way my students } \\
\text { understand }\end{array}$ & 1 & 2 & 2 & 4 & 3 & 6 & 23 & 46 & 21 & 42 & 4.22 \\
\hline $\begin{array}{l}\text { 21. By asking questions during class, I } \\
\text { help my students gain understanding of } \\
\text { the content taught }\end{array}$ & 3 & 6 & 2 & 4 & 4 & 8 & 20 & 40 & 21 & 42 & 4.08 \\
\hline $\begin{array}{l}\text { 22. I am open to student contribution in } \\
\text { my class }\end{array}$ & 2 & 4 & 2 & 4 & 10 & 20 & 21 & 42 & 15 & 30 & 3.9 \\
\hline $\begin{array}{l}\text { 23. I allow my students to ask each other } \\
\text { questions using English during class }\end{array}$ & 1 & 2 & 4 & 8 & 6 & 12 & 17 & 34 & 22 & 44 & 4.1 \\
\hline $\begin{array}{l}\text { 24. I ensure that my students know what } \\
\text { areas they need to work on in order to } \\
\text { improve their results }\end{array}$ & 1 & 2 & 5 & 10 & 8 & 16 & 23 & 46 & 13 & 26 & 3.84 \\
\hline $\begin{array}{l}\text { 25. I give my students opportunities to } \\
\text { ask questions }\end{array}$ & 1 & 2 & 4 & 8 & 8 & 16 & 18 & 36 & 19 & 38 & 4 \\
\hline $\begin{array}{l}\text { 26. My students know what the } \\
\text { evaluation criteria for their work are }\end{array}$ & 2 & 4 & $\begin{array}{l}1 \\
0\end{array}$ & 20 & 9 & 18 & 16 & 32 & 13 & 26 & 3.56 \\
\hline $\begin{array}{l}\text { 27. I ensure that my students know what } \\
\text { they can learn from their assignments. }\end{array}$ & 1 & 2 & 3 & 6 & 14 & 28 & 24 & 48 & 8 & 16 & 3.7 \\
\hline $\begin{array}{l}\text { 28. I can recognize when my students } \\
\text { reach their language learning goals. }\end{array}$ & 0 & 0 & 2 & 4 & 7 & 14 & 29 & 58 & 12 & 24 & 4.02 \\
\hline
\end{tabular}

As shown in Table 4.2, the descriptive analysis of the data indicates that the mean scores received for the statements 17-28 were close to the scale. Most of the participants of the study have chosen "Neutral" or "Agree" for the questionnaire items. The highest mean (4.22) scored for Statement 20 (see Table 4.2). This is also recorded as the highest score mean in the questionnaire. Most of the participants have selected "Agree" or 
"Strongly Agree" for this statement. Meaning that the instructors are keen on providing questions for the students in a way that could match the students' ability of understanding. Moreover, Black et al. (2003) claimed that the teachers have to be aware of the three themes before asking the questions to the students: first, the question has to have its value. Next, the students have to have enough time to think before answering. Last, the teacher has to provide the students more follow-up questions and make sure the students understood everything. On the contrary, the lowest mean is (3.56) has been marked for Statement 26 demonstrating that there is fewer students' awareness of the process of evaluation. The students' knowledge about the teacher's own method of assessment is somehow restricted. However, some educators such as Fisher, Waldrip and Dorman (2005) suggested that the students should be asked in making decisions regarding assessments. Additionally, we can also add that $\% 20$ of the participants disagreed to share their own evaluation criteria with the students (See table 4.2). As a result, the students would not be involved in the process of evaluation and they would not be aware of their own progression. However, formative assessments (self-assessments, peer-assessments, and group-assessment) have to be based on validity and reliability, which they call "Criterion" that the teachers and the students can understand applying to rate the work (Black \& Wiliam, 1998; Herrera et al., 2007).

Research questions: 3. What types of formative assessment do English language instructors prefer to use?

The questionnaire allowed the participants to select more than one method of assessment among the sixteen suggested methods: Essay-type exam, Short-answer exam, Fill in the blank, Multiple choice, True-False, Matching, Oral presentation, Oral exam, Drama, Project, Portfolio, Performance assessment, Peer assessment, Self-assessment, Group work, Observation form, Structured grid, Rubric, Others. As shown in Table 4.3 University instructors showed their most interest to the Multiple-choice and the Short-answer Exam methods of assessment, which are not considered as methods of formative assessment. The frequency of their usage and related percentage was \%58.0 for the Short-answer Exams and $\% 60.0$ for the Multiple-choice Exams.

Table 4.3: The first preferable methods of assessment

\begin{tabular}{lccc}
\hline & & Count & Percentage $\%$ \\
Short-answer Exam & None & 21 & $42.0 \%$ \\
& Ticked & 29 & $58.0 \%$ \\
Multiple Choice & None & 20 & $40.0 \%$ \\
& Ticked & 30 & $60.0 \%$ \\
\hline
\end{tabular}

Ticked: preferred option; None: un-preferred option

Reflecting on the findings of the study, it became clear that the participants of the study prefer using the classical methods of assessment. More specifically, they prefer using short-answer and multiple-choice exams. This may present the fact that the English instructors believe that summative ways of assessment are the only methods of assessment that could elaborate the accurate level of the students' ability. Accordingly, the teachers are less able to provide new information to their students via the traditional forms of assessment; however, Multiple-choice and others which are similar could help the schools to compare their students (Herrera et al. 2007). On the other hand, short-answer exams can also be useful to reduce the students' anxiety while they are asked to give short answers rather than writing long essays (Berkowitz, Desmarais, Hogan, \& Moorcroft, 2000).

However, there are numerous methods of assessment, which are ticked almost by the half of the participants meanwhile the rest have left them un-ticked as shown in Table 4.4 Essay Type, Fill in the Blanks, True and False, Matching, Oral Presentation, Peer Assessment and Group Work exams. Interestingly, essay type, oral presentation, peer assessment and group work exams are considered as methods of Formative assessment which are used by the University instructors during the process of learning. 
Table 4.4: The second preferable methods of assessment

\begin{tabular}{lccc}
\hline \hline & & Count & Percentage $\%$ \\
Essay Type Exam & None & 25 & $50.0 \%$ \\
Fill in the Blank & Ticked & 25 & $50.0 \%$ \\
& None & 24 & $48.0 \%$ \\
True or False & Ticked & 26 & $52.0 \%$ \\
& None & 22 & $44.0 \%$ \\
Matching & Ticked & 28 & $56.0 \%$ \\
Oral Presentation & None & 23 & $46.0 \%$ \\
& Ticked & 27 & $54.0 \%$ \\
Peer Assessment & None & 26 & $52.0 \%$ \\
Group Work & Ticked & 24 & $48.0 \%$ \\
& None & 23 & $46.0 \%$ \\
& Ticked & 27 & $54.0 \%$ \\
\hline
\end{tabular}

Ticked: preferred option; None: un-preferred option

Moreover, the rest ten choices; Oral exams, Drama, Project, Portfolio, Performance Assessment, SelfAssessment, Observation Form, Structured Grid, Rubric and Others are considered as the third preferred methods of assessment by English language instructors as shown in table 4.5. However, these types of exams are mostly related to the practice of the formative assessment (Black et al. 2003).

Table 4.5: The third preferred methods of assessment

\begin{tabular}{lccc}
\hline \hline & & Count & Percentage $\%$ \\
Oral Exam & None & 32 & $64.0 \%$ \\
Drama & Ticked & 18 & $36.0 \%$ \\
& None & 43 & $86.0 \%$ \\
Project & Ticked & 7 & $14.0 \%$ \\
& None & 33 & $66.0 \%$ \\
Portfolio & Ticked & 17 & $34.0 \%$ \\
& None & 34 & $68.0 \%$ \\
Performance Assessment & Ticked & 16 & $32.0 \%$ \\
& None & 34 & $68.0 \%$ \\
Self-assessment & Ticked & 16 & $32.0 \%$ \\
Observation Form & None & 33 & $66.0 \%$ \\
& Ticked & 17 & $34.0 \%$ \\
Structured grid & None & 38 & $76.0 \%$ \\
& Ticked & 12 & $24.0 \%$ \\
Rubric & None & 45 & $90.0 \%$ \\
& Ticked & 5 & $10.0 \%$ \\
Others & None & 42 & $84.0 \%$ \\
\hline
\end{tabular}

Ticked: preferred option; None: un-preferred option

To sum up, the teachers in general tend to dedicate the tests to measure the students' progression through learning (Boraie, 2012, Stiggins, 2008). In other words, the teacher's understanding for assessment mostly links to summative and traditional, they believe that the assessments should be set in way that could tell that whether the students received what they have been taught or not.

\section{Conclusion}

Reflecting on the findings of the study, we might conclude that most of the English language instructors' attitude towards the practices of formative assessment is neutral. It also became clear that, while sixteen English language instructors are quite familiar with formative assessment practices, thirty-four of them have not taken any training courses on assessment. The first research question of the study aimed at finding English language instructors' perceived monitoring practices of formative assessment. The findings of this study revealed that language instructors are well-aware of the importance of giving support to their students in the language learning process. This conclusion is in line with the arguments put forward by Black and William (1998). Black and William (1998) highlight the importance of scaffolding when the students are on task. They believe effective 
feedback has a positive influence on students' language achievement. Regarding monitoring practices of formative assessment, we might also conclude that all of the language instructors give feedback about the examination results yet less than half of them ignore sharing the examination papers with the students, which rarely help the learners to learn from their mistakes and/or their weaknesses to improve their language skills as pointed out by many researchers (Wiggins \& McTighe, 2007; Black \& William, 1998; Herrera, Murry \& Cabral, 2007).

The second research question of the study focused on the identification of English language instructors' perceived scaffolding practices of formative assessment. The findings of this study revealed that almost all of the instructors are open to make modifications in their teaching practices on noticing any problems in students' achievement of their learning goals. Additionally, we might conclude that most of the participants in the study are well aware of the importance of using questioning strategies to improve student learning. For this reason, they give the students opportunities to ask and answer teacher and peer questions. It also became clear that the teachers check students' understanding of the topics in discussion through comprehensible follow-up questions. However, we found out that only a few of the participants give less importance to sharing the success criteria with the students, which is a key feature of formative assessment (Black \& William, 1998; \& Fisher, Waldrip and Dorman, 2005).

The third research question of the study focused on the identification of the types of formative assessment English language instructors prefer to use. The findings of the study revealed that the instructors prefer using the Multiple-choice and the Short-answer Exam methods of assessment the most, which are not considered as methods of formative assessment Black \& William, 1998). The second most frequently preferred assessment methods are Essays, Fill in the Blanks, True and False, Matching, Oral Presentation, Peer Assessment and Group Work exams. Finally, Oral exams, Drama, Project, Portfolio, Performance Assessment, Self-Assessment, Observation Form, Structured Grid, are Rubric considered as the third preferred methods of assessment by English instructors.

Briefly, the English language instructors mostly apply the traditional methods of assessments with its all strategies; however, they are not completely against the alternative methods of assessment. In conclusion, we can state that the English language instructors would like to assess their students through the traditional methods of assessment rather than the resent ones. Reflection on the findings, it becomes clear that the participants of the study believe that summative assessments with its various types are more applicable for the university students than formative assessments.

\section{REFRENCES}

Berkowitz, A. J., Desmarais, K.H., Hogan, K., \& Moorcroft, T. A. (2000). Authentic assessment in the informal setting: How it can work for you. The journal of Environmental Educational, 31(3), 20-24.

Black, P., \& William, D. (1998). Inside the Black Box. Raising standards through classroom assessment. Phi Delta Kappan. 80. pp. 139-144.

Black, P., \& William, D. (2009). Developing the theory of formative assessment. Educational Assessment, Evaluation and Accountability, 1 (1) pp. 5-31.

Black, P., Harrison, C., Lee C., Marshall, B., \& William, D. (2003). Assessment for learning. Putting it into practice. Buckingham, UK: Open University Press.

Boraie, D. (2012) Formative vs Summative Assessment: Does it matter? TESOL Connections, September 2013. Retrieved on 10 December 2018 from http://newsmanager.commpartners.com/tesolc/issues/2012-0901/3.html.

Dhindsa, H., Omer, K., \& Waldrip, B. (2007, August 1). Upper Secondary Bruneian Science Students' Perceptions of Assessment, International Journal of Science Education, 29(10), 1281-1280.

Fisher, D. L., Waldrip, B. G., \& Doeman, J. (2005). Student Perceptions of assessment: Development and validation of a questionnaire. Paper presented at the Annual Meeting of the American Educational Research Association, Montreal, Canada.

Gottlieb, M. (2006). Assessing English language learners: Bridges from language proficiency to academic achievement. Thousand Oaks, CA: Corwin Press.

Herrera, S. G., Murry, K. G., \& Cabral, R.M (2007). Assessment accommodations for classroom teachers of culturally and linguistically diverse students. Boston, MA: Pearson Education Inc.

Hüseyin Ö. (2014). Turkish Teachers' Practices of Assessment for Learning in the English as a Foreign Language Classroom. Journal of Language Teaching and Research, Vol. 5, No. 4, pp. 775-785, July 2014.

Lavrakas, P.J. (2008) Encyclopedia of survey research methods. Sage Publications, Inc., Thousand Oaks.

Mertler, C. A. (1998). Classroom assessment practices of Ohio teachers. Paper presented at the meeting of the Mid-Western Educational Research Association, Chicago, IL.

Ron J., Pat-El. \& Harm, T., \& Mien S., \& Paul V. (2013). Validation of Assessment for Learning Questionnaires for Teachers and Students. British Journal of Educational Psychology (2013), 83, 98-113. 
Sharma, S. (2006). Constructivist Approaches to Teaching-Learning. NCERT, New Delhi.

Stiggins, R. (2008). Assessment Manifesto: A Call for the Development of Balanced Assessment Systems. Portland, OR: ETS Assessment Training Institute.

Struyven, K., Dochy, F., \& Janssens, S. (2005, August 1). Students' Perceptions about Evaluation and Assessment in Higher Education: A Review. Assessment and Evaluation in Higher Education, 30(4), $325-$ 341.

Thomas, S. C. Farrell, George, M. Jacobs. (2010) Essentials for Successful English Language Teaching. Continuum International Publishing Group. pp. 10-11.

Volante, L. \& Fazio, X. (2007). Exploring teacher candidates' assessment literary: Implications for teacher education reform and professional development. Canadian Journal of Education, 30, 3. pp. 749-770.

Wiggins, G., \& McTighe, J. (2007). Schooling by design: Mission, action and achievement. Alexandria, VA: Association for Supervision and Curriculum Development.

\section{About the Author}

Mohammed Sherko Taher Malazada is the author of the article. He was born in 1989 Erbil, Kurdistan region/ Iraq.

Education

- $\quad$ (Master Degree) English Language and Literature (2019)

Department of English Language and Literature- Istanbul Aydin University- Istanbul/ Turkey.

- (Bachelor's Degree) English Language and Literature (2010-2011)

College of Education for Human Sciences - English Language - Salahaddin University- Erbil/ Iraq. 